International Journal of Political Economy, vol. 39, no. 2, Summer 2010, pp. 41-57. (C) 2010 M.E. Sharpe, Inc. All rights reserved.

ISSN 0891-1916/2010 \$9.50+0.00.

DOI 10.2753/IJP0891-1916390204

DOMENICA TROPEANO

\title{
The Current Financial Crisis, Monetary Policy, and Minsky's Structural Instability Hypothesis
}

\begin{abstract}
The object of this work is to evaluate the monetary policy issues that arose during the financial crisis of 2007-8 according to Minsky's thought. It is argued that Minsky's idea of structural instability may fit the policy problems linked to the crisis. In particular, Minsky's contribution to the theory of central banking is used to evaluate the conduct of the Federal Reserve during the crisis. Minsky's reading of the roles of the central bank in the presence of sophisticated markets and securitization is helpful in understanding both the failure of the Federal Reserve in preventing the crisis and the relative success in mitigating the effects. This apparent success notwithstanding, the paper warns that economic policy, to promote stability, must enlarge the stability field of the system by changing the type of institutions operating there and their business habits.
\end{abstract}

Keywords: central banking, financial crisis, Minsky, monetary policy, securitization, structural instability.

The objective of this article is to evaluate the monetary policy issues that arose during the financial crisis of 2007-8 according to Minsky's thought.

\section{Minsky and the Current Crisis}

The Debate on Minsky's Financial Fragility Hypothesis and the Current Financial Crisis

The scholarly literature on Minsky and the financial crisis has until now concentrated on whether Minsky's theory of financial instability may be used to explain the cur-

Domenica Tropeano is an associate professor in the Department of Economic and Financial Institutions, University of Macerata, Italy. 
rent crisis (see Bellofiore and Halevi 2009; Davidson 2008; Kregel 2008). Bellofiore and Halevi (2009) argue that this is possible, though with several adjustments. The original financial instability hypothesis was developed in the historical climate of a growing economy with inflation problems. Minsky's thesis that the instability of a capitalist economy is endogenous has been formalized in models in which the main variable that mattered for business cycle fluctuations was investment (see Bellofiore and Ferri 2001). In the current evolution of capitalism, Bellofiore and Halevi (2009) warn that some aspects of the original story told by Minsky may not be retained. One aspect is the growing indebtedness of the corporate sector as the boom phase of the business cycle develops, which would not be realistic anymore. The corporate sector, rather receiving funds from the other sectors, is lending funds to them. The second aspect is the centrality of investment in the generation of the different phases of the cycle. Currently, monetary policy has managed to make debt-financed consumption the main item in aggregate demand. Further, globalized capitalism has managed to avoid inflationary pressures through relocation and compression of wages.

Kregel (2008) writes that Minsky's ideas of margin of safety, debt deflation, and financial fragility are all important for understanding the current crisis. He thinks, however, that Ponzi financing and declining margins of safety are not the results of an endogenous process as usually explained. The crisis stems from the way creditworthiness is evaluated in the new originate and distribute model. The endogenous financial fragility hypothesis turns on the point that the expansion itself validates riskier projects. It is not that bankers are becoming increasingly less risk averse than they were before the expansion, it is simply that the results from past history are better and, given these good performances, they are inclined to extend credits to the people who have performed well. In turn, the expansion enables people to repay their past loans and thus validates the bankers' choices (see Kregel 2008: 10). However, the main features of the current crisis are not overinvestment, excess borrowing, and concentration of risk. The current crisis shows indeed declining margins of safety and Ponzi financing, but these events are not generated by the process described above.

According to Kregel, the declining margin of safety and the Ponzi financing depend on the structural change that occurred in the financial system in the United States. The type of institutions present and their conduct has led to a sort of builtin structural underestimation of risk and Ponzi attitude to financing. In a certain sense, the number of Ponzi units was not random or increasing with prosperity (pro-cyclical) but depended strictly on the operating rules of American nonbank financial institutions. What Kregel means is that there was an endogenous shift neither from sound to bad financing nor from speculative to Ponzi units. Simply, the change in regulation and the environmental constraints (read securitization) made most financial units arise as Ponzi units. Those financial units were profitable only by operating under Ponzi-type behavior; they were created with the aim of being like this. 
Kregel writes that the changes to the Glass-Steagall Act jointly with the Basel Accord have changed the way banks operate. They aim mainly at earning income from fee and underwriting operations and, for various reasons also linked to regulation, shift lending operations to off-balance sheet entities. Thus, they do not have any more loans on their balance sheets, and they are no longer concerned with the risk of the borrowers. The shifting out of loans to other entities and the originate and distribute model have changed the evaluation of credit risk, which is no longer performed by banks but by rating agencies (see Kregel 2008: 12).

The banks no longer lend directly; they sell their securitized loans to the intermediaries, which in turn issue their own paper to buy it. Those intermediaries depend on the interest rate margins to earn their profits and are subject to liquidity, interest rate, and other risks. They were relying on spread income as a source of revenue. As the Fed tightened and the term structure changed shape, with short-term rates higher than long-term ones, spreads became negative. The only cushion of safety foreseen was the overcollateralization of the commercial paper relative to riskier investment notes. This was insufficient to face the risks involved in this activity (see Kregel 2008: 18).

The increase in fragility was not due to the declining margin of safety. It just showed how inaccurate the estimates and the classification of risks by rating agencies had been. These estimates were based only on the correlations between the credit characteristics of previous borrowers in relation to changes in financial conditions. Since the beginning, therefore, these practices narrowed the margin of safety. During the crisis this insufficient margin of safety, which had been insufficient right from the start, became evident (see Kregel 2008: 12). Kregel concludes that the crisis was due not to a declining margin of safety but to the revelation that this margin of safety had always been terribly low.

I wish to argue that there is a more general way to reconcile Minsky's theory of financial instability with the current crisis. The starting point of Minsky's theory was the rejection of the neoclassical synthesis. He denied that Keynes's instability hypothesis could be reduced to introducing liquidity preference in the equation for money demand. The instability Keynes hinted at was more pervasive than that, and it was linked to the notion of radical uncertainty. Uncertainty mattered, insofar as the capitalist economy was a sophisticated financial economy. In a period in which investment was the main engine of aggregate demand, this meant recognizing that investment was a flow and had a price deeply influenced by expectations of future financial variables in contrast to the price of the capital stock. Sudden shifts in expectations might produce fluctuations in the demand price of investment and then produce a deep recession if the central bank and the government do not intervene to sustain aggregate demand and profits.

An interpretation of Minsky's financial fragility theory, which hinges on structural instability rather than on dynamic macroeconomic instability, may be found in Vercelli (1999). Vercelli (1999) draws a distinction between dynamic instability and structural instability. Dynamic instability means that a system, after a disturbance, 
which will bring it beyond its equilibrium position, will tend either to go back to the initial position again or to reach another equilibrium configuration. Structural instability, instead, would mean that a small disturbance, even a very small one (infinitesimal), may change the qualitative characteristics of its dynamic behavior (see Vercelli 1999: 4). This means that a shock may have different effects according to the way it changes the parameters of the system. These parameters may be the distribution of hedge, Ponzi, and speculative units in the system but also the propagation velocity (see Vercelli 1999) and the potential damage, I would add, due to repeated rounds of falling securities' prices, a sort of multiplier of an initial loss.

Vercelli (1999) traces Minsky's notion of instability to his interpretation of Keynes. To interpret Keynes by using the notion of structural instability means to stress that the main behavioral relations defined in the general theory, such as the propensity to consume and the marginal efficiency of capital, may be subject to sudden and unforeseeable shifts. He defines in the following his interpretation of Minsky's theory:

The cycle is seen in its essence as the regular repetition of structural states characterized by a different degree of financial fragility which has to be interpreted in terms of structural instability. Both endogenous and exogenous factors play a crucial role and interact in a complex way. The endogenous factors are not grounded in disequilibrium dynamics (convergent or divergent) as in the macrodynamic approach but in the intrinsic structural instability of a monetary economy and its evolution. On the other hand this approach gives also a different, enhanced, role to exogenous shocks which may trigger sizeable qualitative changes in the economic behaviour of the system and are not subject to probabilistic restrictions in their properties such as stationarity or symmetry. (Vercelli 2001: 11; emphasis added)

From this point of view, we do not necessarily need a macroeconomic theory of the trade cycle based on investment to use the financial fragility hypothesis. The evolution of legislation and business strategies in the past twenty years has provided a whole range of exogenous shocks to transform the way financial fragility shows itself. Within this framework it may be entirely right that declining margins of safety are not the result of an endogenous process. Vercelli (1999) adds that the exogenous shocks in the case of a single unit may be interpreted as a change in the rate of interest and that the endogenous cycle may be related to the financial position of units in the taxonomy of hedge, speculative, and Ponzi types of financing. This, however, is just an example. The exogenous shock may be another one among many, and the definitions of units may change as well.

The distribution of units among the three categories and the reciprocal relations among them determine the degree to which a financial system is fragile. If the structural interpretation of fragility is chosen, then the endogenous story can be reshaped as follows. The structural instability of the system had greatly increased before the crisis, due to the high number of Ponzi units present from the beginning. Not only has the crisis caused a transformation of balance sheets characteristics, that is, from 
hedge and speculative into Ponzi, but it has, through the breakdown of organized exchanges, made the same Ponzi units unable to go on with their businesses. In a way, this is an endogenous change too. It has only to be added to the picture that, under certain institutional conditions, Ponzi units may survive without going into bankruptcy for a longer time than that which is usually assumed.

\section{Minsky on the Structure of Financial Markets and Structural Instability}

Minsky tries to envisage a relation, which is not linear, between the instability of the units and the instability of the system. In the current crisis, both the presence of a high number of Ponzi units in the financial system (see Kregel 2008) and the complexity of economic structure would indicate that potential losses might be very big. He writes that the stability range of a financial system is an endogenous phenomenon that depends on financial structure and institutional arrangements. The exogenous elements are instead the public sector and central bank regulation. The stability range tells us the maximum amount of a shock a financial system may absorb without deviating from the initial equilibrium position. Of course, the smaller the stability range is, the smaller the shock that leads to a deviation of the financial system from its initial position may be. When the stability area is tiny, even a small shock can cause a permanent deviation from equilibrium.

There are two essential determinants of the stability field: the degree to which a narrow relation exists between regular inflows from income and outflows and the weight in portfolios of assets that can be sold at their historical accounting values. The narrower the relation between income inflows and payments outflows and the greater the weight of assets that must be sold at market values, the smaller the stability field of the system. A third but less important determinant of stability is the degree to which the prices of assets incorporate optimistic expectations made in a period of euphoria (see Minsky 1982).

The stability field of the financial system in the United States before the crisis was indeed very thin. The ratio of assets, whose value depends on the behavior of the system to external assets, was indeed very high; for the safe assets, such as public debt and the assets whose price could be stabilized by central bank action, were only a small fraction of total assets. Moreover, the weight in portfolio of assets, which could be sold at their historical accounting values, was very low because of the widespread practice of "mark to market" accounting.

The link between inflows and outflows was indeed very tight because the units were operating with no capital and reserves at all, so that all the payment obligations could be met only if an inflow of the same amount was received at the same time. The units were very highly leveraged. Often the maturities of assets and liabilities held in portfolio were different, so that even the contractual obligations on the liabilities did not match the time pattern of income received on assets. Liabilities were short term, whereas assets were long term. All these elements - the high number of Ponzi units within the financial system, the increase in layering, and the limited ability 
of the central bank to stabilize the system through monetary policy and to act as a lender of last resort to the whole financial system — made the so-called stability range terribly small. Minsky talks about transformations in portfolios as a way to react to the money supply restriction, which happens at the end of a long boom period. In this case, the tendency toward financial innovation does not seem to arise from the necessary tightening of monetary policy after a long expansion but just for the aim of getting a higher profit rate by increasing leverage and layering.

The first signs of the crisis, in the summer of 2007, perfectly mirror Minsky's observations on the importance of structural stability. Dodd (2007) asks himself how a modest increase in delinquent subprime mortgages, which added about $\$ 34$ billion in troubled loans, might disrupt the $\$ 57$ trillion U.S. financial system. Although lax if not fraudulent lending policies are responsible for the increase in nonperforming loans, the impact on the financial system is much greater than expected (see Dodd 2007: 15). The answer he gives to the question is that the mortgage crisis is as much about the breakdown of the structure of U.S. financial markets as it is about bad debt.

This means that the potential losses resulting from a shock to the system depend on the relation among the units. If the number of links (of bilateral and multilateral relations) among the units is high, then the loan recalling and asset sales will be considerable. Dodd (2007) shows us with a graph what happened during the first months of the financial crisis in the United States. This graph is a sort of map of the mutual relations within the financial system. The system, indeed, broke down because of the interaction between different segments of financial markets and of reciprocal debts among financial institutions. The first institutions to face trouble were the hedge funds.

When the crisis started, markets became illiquid at the same moment that hedge funds had to sell assets to repay losses. As a result, hedge funds stopped trading and the collateralized debt markets and other derivates markets ceased to exist. The issuers of these instruments ceased to issue them. With no market, the originators could not sell the loans they had made anymore. The problem then passed from the market for collateralized debt to the market for commercial paper. Because this paper was asset backed and the assets, which were behind this paper, were the collateralized debts, buyers was immediately aware that this paper was worth nothing or very little, so they stopped buying it.

Financial markets were multilayered because of the new financial instruments such as derivatives, particularly credit derivatives, and the financial institutions, which traded in them, were highly leveraged. Under these conditions, even a small shock might destroy the whole building. Minsky writes,

Financial institutions usually take a position in financial assets by issuing their own liabilities. The contracts they own or issue include the promise to pay cash on demand at a predetermined rate. These institutions may get additional income sources by buying and selling contracts in markets. Then the uncertainty they face is not only related to the expected shortfalls and excesses of their cash flows but 
also to the state of the various money markets when they need to make positions by operating in them. (1982: 185)

This excerpt is particularly important in the interpretation of the current crisis. According to the financial fragility interpretation, as a business cycle theory this would not be important. The usual story of how a financial crisis starts would be the following. A rise in interest rates would lower, through present value calculations, all the expected future incomes and would make the current interest expenditures rise, thereby causing a revision of expected sales and profits and a reduction in planned investment. This, in turn, through the aggregate demand repercussions, would cause a recession.

In the current crisis, the most important aspect is the second one stressed in the quote above, namely, the state of markets when operators need to make positions in them. Many financial institutions and many nonfinancial ones were unable to continue their normal operations not because of downward revision of expectation but because of the sudden disappearance of markets. Liquidity in markets is the channel through which the qualitative consequences of a shock to the system emerge. If liquidity is abundant and it is very easy to resell assets after having bought them, then even Ponzi units may continue their businesses for a long time.

As long as the state of the markets is such as to ensure profitable reselling and leveraging, the process may go on. If a very small change occurs, the whole process will proceed in the opposite direction because all units will try to deleverage by selling assets. The liquidity of the markets for the new financial instruments was not ensured in any way, and the institutional environment did not care about it at all. All this became evident during the financial crisis. As Kregel writes, there is no endogenous mechanism through which previously hedge or speculative positions turned out to become speculative or Ponzi-like. Ponzi units were as such right from the beginning, and they could continue to carry out their businesses just because they succeeded in getting greater and greater debts on the market. Those debts were contracted in the form of securities. These units were issuing their own debt, so, as long as the market agreed to buy it, they could go on and enjoy profits. As the markets ceased to work, this game was no longer feasible. An extreme case of structural instability arises when, after a shock, not only do some units go into bankruptcy but the markets themselves disappear as well.

In this way, a shock may cause not only a temporary deviation from a dynamic equilibrium (i.e., a reassessment of balance sheet positions until the expected future inflows rise again and the economy recovers) but also a qualitative change. In this particular case, the qualitative change happened because of the disruption of the markets for certain financial instruments and the impossibility of carrying out exchanges. At this point, the role of the central bank in the working of money markets needs to be introduced. Under these conditions the role of the central bank and of the government was not only to provide liquidity and to support profits to avoid a downward revision of expected future incomes and a fall in planned investment but also and more importantly to reconstruct markets. 


\section{Minsky on Central Banking}

Let us recall some of Minsky's important insights on the role of central banks in financial markets, which, although written a long time ago, are appropriate for describing the roles of central banks in a world of sophisticated financial markets with a layered structure.

According to Minsky, the role of the central bank is not only to intervene in difficult situations but also to help markets work under normal conditions every day. He writes that the central bank has to maintain orderly conditions in all markets for financial markets to be efficient. To maintain orderly conditions in financial markets means to protect those who hold positions in these markets. In particular, secondary markets must be developed to generate liquidity when the system is working smoothly and to ensure protection when the system is working badly. Minsky stresses that the dealers who operate in those markets must have access to central bank refinancing because the only universally accepted guarantee is that of the central bank. Further, he argues that if the central bank could stabilize certain private assets, these assets would become sources of liquidity at certain warranted prices.

Minsky (1982) observed that only a small part of the reserve base of banks comes from discount operations at the central banks. Discount at the central bank may perform three roles: a temporary cushion against pressures on the money market, a regular source of reserves, and a means to stabilize prices during a crisis. For the central bank to act as a lender of last resort during a crisis, the bank must normally deal with a great part of markets where securities are traded. One way to make this happen is to encourage the creation of secondary markets for activities and organize them in such a way that the central bank regularly finances its dealers. The central bank action as a lender of last resort must be such as to avoid the fall in the value of assets, which leads to a recession.

Minsky looks at the central bank not just as the entity obliged to give emergency loans during a crisis but also as an important institution that ensures normal operations in markets. However, he is worried that the process of securitization may make it difficult for the central bank to act in this way. Minsky (2008) warned that securitization might make the central bank unable to control the supply of money. In fact, the financial institutions, which work in the securitization process, do not hold any reserves and capital. Minsky also stresses the danger that they pose to financial stability: "Securitization lowers the weight of that part of the financing structure that the central bank (the Federal Reserve in the United States) is committed to protect" (2008: 3).

Minsky writes that in a securitized world, rating securities' revision of the risk class of securities may cause a rush to sell the underlying assets, which in turn will start the debt deflation process. This is, actually, what happened in the first months of the crisis at the end of 2007 (see Dodd 2007). He warns also that the market for securitized assets will be a thin market if the price and quality of securities deterio- 
rate (see Minsky 2008). These ideas fit the events under discussion perfectly.

In particular, Minsky stresses the point that the central bank must become a lender of last resort to the money market not only to the distressed credit institutions (1982: 241). He recalls that the classic operating rule of the central bank of England was to act as the lender of last resort to financial institutions such as the discount houses, which controlled a large part of the money market. He observes too that the effectiveness of the central bank policy depends on the way its actions affect the structure of the money market. The effectiveness of a certain monetary policy depends on the institutions present in the market and on their operating habits. Only if the environment is static can the effects of monetary policy be reasonably foreseen. In a context of rapid evolution of markets, the same does not hold.

The action of the central bank may have different effects in different institutional contexts. Financial markets change from either their evolution or legislation. Minsky considers, in particular, an example that may shed light on the conditions of the current crisis as well. He writes about the financing of institutions, which are dealers in the market for public securities and discusses the repurchase agreements that they use to finance themselves. The dealers, who traded in the public securities market at that time, held in their books repurchase agreements with nonfinancial corporations who employed their liquid funds in this way. Minsky describes the implications of this change in financing. If nonfinancial corporations withdrew their funds, the dealers would be compelled to ask banks for credit.

Given the term structure of interest rates prevailing at the time, this could be very costly. Minsky thinks that they would not have been able to take positions in a market that was shrinking. If the Federal Reserve did not intervene to finance them, interest rates would rise very rapidly. This induces Minsky to conclude that a money market that depends on short-term credit by nonfinancial corporations requires an institutional setting that allows reserves to be unloaded in the market whenever liquidity problems arise. The situation of the short-term money market during the current crisis was far worse than that described by Minsky in the example. Many financial institutions operating in various segments of the system had no reserves at all, having no legal obligation to hold them, and regularly sold assets to raise money. Unfortunately, the liquidity of those assets was not warranted at all.

On the assets side of most institutions, including those trading in commercial paper, there were collateralized debt obligations issued by special purpose vehicles. The regular selling of those assets ensured liquidity in case of necessity. As the first sign of problems in the mortgage market appeared, the market for collateralized debt obligations ceased to exist. Those who had these instruments in their portfolio could no longer sell them to raise money and, in turn, fulfill their own obligations. Thus, the crisis spread to all segments of the market.

Most financing of the institutions operating in the market for loans and mortgages was made through reciprocal lending within the financial system itself. Repurchase agreements were the tool generally used to get new financing. In a repurchase agreement, the borrower sells an asset today at a price that is below the market price and 
agrees to repurchase it at a certain date at a price fixed in advance. The difference between the current market price and the repurchase price of the security is called the haircut. Adrian and Shin (2008b) show that most of the financing by nonbank financial intermediaries, namely dealers and brokers, happened using this instrument.

The variable that mattered for the cost of financing was not the interest rate but the haircut. The haircut largely determines the quantity of funds that intermediaries can raise. In distressed times, the haircut rises sharply, and the possibility of borrowing based on existing assets in their portfolio is thus limited. This, in turn, hinders the dealers and brokers in performing their main role: to make markets for securitized products, whose availability determines the credit supply for consumers and nonfinancial firms. Brokers and dealers fund themselves with short-term debt in the form of repurchase agreements and, in part, pass this debt back to hedge funds through reverse sale and repurchase agreements. They invest instead in longer-term, less liquid securities.

The variable that matters most for these transactions is the price of securities exchanged. The current price is crucial, because it determines the extent of the loans that can be obtained and the future repurchase price. Under these conditions, the central bank, if it wants to prevent a financial crisis, may avoid any fall in the price of securities for whatever reason. Today, through the liquidity injections and its special interventions, the central bank has succeeded in restoring the price of assets. Stock values have risen again by 50 percent at the time of writing. This helps in restoring the high leverage by financial institutions and their speculative practices while at the same time allowing them to pursue the same management policies that led to the current crisis.

\section{Central Bank Interventions During the Current Crisis in the United States}

In the first stage of the crisis, the Federal Reserve tried to solve the liquidity problem by lowering the interest rate. This was repeated many times, without any improvement in market conditions. The spread between the interbank market interest rate and the so-called overnight indexed swap (OIS) rate at the same maturity widened instead of narrowing.

The failure of monetary policy to deal with the crisis was not a surprise, as the problem of carrying out monetary policy in a securitized system with a large part consisting of nonbank financial institutions has been mentioned. The central bank had lost the power to control the financial system for quite some time, according to some scholars (see D’Arista 2009; Kregel 2008). The intervention of central banks offering reserves may work in an institutional environment where banks are the main financial institutions. According to the endogenous money supply hypothesis, the money supply process goes the other way around with respect to textbook presentations of the money multiplier.

Deposits do not create credits, rather, credits create deposits. However, given the 
institutional change in the system, it is difficult to see any link between deposits and credits at the banking system now because of the enormous space gained by nonbank financial institutions. Erturk and Ozgur (2008) find that empirical relation is indeed very weak. Banks have become independent from required reserves and core deposits and have even avoided the constraints posed by capital requirement through securitization.

In the period before the crisis, the extension of credit did not follow an increased trade volume, but it was perhaps driven by asset price expectations (see Erturk and Ozgur 2008). This thesis seems to find support in other studies on the composition of the balance sheets of financial institutions, particularly investment banks. Adrian and Shin (2008a, 2008b) find that the lowering of the federal funds rate is positively correlated with an increase in the rate of growth of assets in the balance sheets of investment banks. The only effect of a lax monetary policy, according to Adrian and Fleming (2005) and Adrian and Shin (2008a, 2008b), was to artificially inflate the sizes of the balance sheet of investment banks.

Every time monetary policy was relaxed, they borrowed more funds on the markets and then used the proceeds to buy financial assets. In this way, both sides of their balance sheets showed higher and higher values. The process was profitable because the cost of debt was very low and the prices of financial assets were rising. Thus, the easing of monetary policy did not bring about an increase in credit supply in the conventional sense; it increased only the assets of financial institutions, which do not enter into money aggregates. The transmission channel did not depend on the interest rate but on the haircut (see Adrian and Shin 2008a).

During a crisis, liquidity injections do not reach all parts of the financial system. In a securitized system, as Minsky stated, the central bank is committed to protect only a part of the system. Under normal conditions, easing conditions for that part of the system may lead to the expansion of the assets of the whole system. If banks get more credit from the central bank they may, through various arrangements, give more credit to other parts of the financial system. During a crisis, this mechanism does not work. Even if banks receive more credit, they will end up redepositing reserves at the central bank, particularly if they are remunerated. The flow of credit from the banks to the nonbanks, or from commercial banks to other financial institutions, stops under periods of stress (see Goodhart 1993). Goodhart (1993) warns against the problems posed by a dichotomized financial system.

Some research on the financial crisis has dealt with the problem of complexity. The complexity of the financial system would have made interventions by the central bank difficult. The answer would be to change institutional arrangements, particularly those on netting. Brunnermeier (2009) suggests that network and counterparty problems of credit risk played a role in the freezing of the interbank market. He argues that these problems may be more easily overcome if a clearinghouse or another central authority or regulator is introduced that knows who owes what to whom. He suggests that multilateral netting agreements, such as the service provided by SwapClear, can stabilize the system. 
The introduction of structured products, which are typically traded over the counter, would have made the web of obligations in the financial system opaque and would have increased systemic risk. Brunnermeier (2009) provides an example in which the netting of positions between two investment banks would have been possible if there were no counterparty risk involved and if no other financial institutions were involved. If the settlement of positions among banks requires an estimate of other parties' reliability, it becomes extremely difficult and very costly.

The central bank cannot replace the lost trust among institutions-which is owing to the incapacity to value securities in their balance sheets-that are not treated in markets that are regulated and whose liquidity is warranted. Obviously, the role of the central bank in the interbank market is always to replace its own money to the claims of banks to each other. The claims of a bank on another and the debt of the latter owed to the former are always settled by using central bank money, by definition (see Rochon and Rossi 2007). Given the widespread use of derivative instruments, it was difficult to assess the structure of debt and claims among financial institutions and thus the amounts to be netted.

Although the main fault of the central bank is to have let short-term money markets grow without any control, just the opposite of what Minsky recommended, it is illusory to identify the main problem that has led to the crisis as a problem of netting arrangements. Just changing netting arrangements is not a sufficient tool to restore the health of the financial system; rather other measures that tend to avoid Ponzi behaviors are needed. A clearinghouse arrangement would have helped to overcome liquidity problems if the central bank had realized it in due time, but the main problem once the crisis set in was solvency, not just liquidity.

Most agents in the financial system knew that the problem facing financial institutions was not liquidity but solvency. The widespread belief that most financial institutions were virtually insolvent, confirmed by some failures, hindered the exchange. This is why the central bank and the government had to change policy and give direct support to the markets through asset purchases and offers of public guarantee to private transactions. In this situation, the central bank completely changed its role. Instead of simply netting out transactions among banks and acting as the lender of last resort to the banking system, it has become, as Buiter and Sibert (2007) pointed out, a market maker of last resort.

Some markets, which were drying up because there were no intermediaries willing to make deals, as in the commercial paper market, have been revitalized by the central bank, entering the market directly and purchasing the paper. Eventually, its intervention did convince intermediaries to restart their activities again. In the commercial paper market, however, the granting of a state guarantee by the Treasury has also played a role (see BIS 2009; Brunnermeier 2009). The bank had to intervene to buy the bad assets directly and replace them with safe assets, such as state debt. The Treasury had to give its warranty to many products in various markets to make them function again. The result of all these interventions has been an enormous increase in the balance sheets of both the Treasury and the Federal 
Reserve. However, given the slow rate of growth of the economy, this increase does not fuel inflation and does provide the private sector with some good assets to hold in their portfolio (see Papadimitriou and Hannsgen 2009).

We have seen that conventional monetary policy has not succeeded in improving conditions in money markets and that other less conventional measures the central bank has introduced have performed better. These measures are different from monetary policy in that they change the asset composition of the assets side of the central bank balance sheet and do not involve lending reserves. In this way, they should not interfere with monetary policy (see Bernanke 2009; Fleming et al. 2009; Keister et al. 2008). Bernanke (2009), Fleming et al. (2009), and Keister et al. (2008) argue that the increase in central bank assets and liabilities will not lead to an increase in the supply of money.

In particular, the term securities lending facility has been successful. The Fed, after this initial experiment, has planned to and indeed has implemented other facilities aimed at supporting other markets, such as the asset-backed commercial paper market through the Term Asset Backed Securities Loan Facility and the Money Market Investor Funding Facility. The Fed, in addition, plans to purchase long-term securities for its portfolio debt of government-sponsored enterprises. Bernanke (2009) argues that the central bank has switched from conventional monetary policy to these other measures because the federal funds rate has virtually approached its lower bound, which is zero. This has been the result because when many financial institutions were deemed insolvent, the state or the central bank intervened to guarantee for them. This happened either through direct asset purchase or through taking control of these institutions. This is not monetary policy. The result of all these interventions has been an enormous increase in the balance sheets of the Federal Reserve, although this has arisen jointly with the other policy measures taken by the government, whose financial burden weighs on the Treasury to restore the profits of financial institutions. The prospects for the future are a continued money and credit supply expansion to keep these profits high and to make the stock exchange go up again. This action has in part succeeded because there are signs of improvement in the market for bonds and shares.

The restoration of stock exchange values, of course, offers many advantages for the balance sheets of financial institutions and for the pensions of American citizens. The enormous efforts in this direction, however, have not yet been accompanied by a reform of the structure of the financial system. To again use Minsky's words, the monetary policy has avoided a terrible destruction and a fall in output growth even bigger than that experienced hitherto, but it has achieved this goal by supporting the profits, in this case, not of inefficient firms in the real sector but of firms engaging in Ponzi financing in the financial sector. Thus, the conditions for the next crisis are set unless measures are taken to avoid these financing practices in the future (see Tymoigne 2009).

Under the current conditions of capitalism, where profits of the financial sector are a high percentage of total profits, this is a new way to propose the old dilemma: 
either not to intervene and experience a painful recession or intervene to support business profits even if their plans were not successful.

\section{Do These Policies Warrant Financial Stability in the Long Run?}

I have argued that Minsky's theory of financial fragility, interpreted as a theory of structural instability, is useful for interpreting the current crisis. Structural instability means that a small event can change the qualitative characteristic of a system and thus even its dynamic properties. As Minsky wrote, beyond the uncertainty arising from expected inflows and outflows, what matters is the state of markets when people need to take positions in them. Before the financial crisis, although many agents were speculative and Ponzi ones, the extreme liquidity of the markets has allowed them to operate quietly for a long time. When the crisis exploded, a tiny increase in the bankruptcy rate of mortgages caused the breakdown of the whole financial system. The qualitative change that followed in this case was the destruction of markets. The central bank then had to react with a very special set of measures tending to restore the normal operations of markets by ad hoc interventions in many different sectors. Just pumping liquidity into the system was insufficient.

The Federal Reserve, under the pressure of events unfolding to hinder the working of the short-term money markets, has done exactly what Hyman Minsky recommended a long time ago, in the 1960s. It has extended the realm of financial institutions eligible to obtain credit and the range of securities accepted as collateral. In this way it has in part achieved the result of stabilizing the price of those securities, which are mostly traded and which are in the portfolios of the market makers. However, all this has happened too late, after the crisis spread to the real sector. The crisis started in August 2007. The assets of the central bank have increased significantly only during the second half of 2008 up to the time of writing in 2009.

Given that the structure of financial markets has collapsed, the interventions were not directed merely to provide liquidity and support nonfinancial business profits. We read in Minsky (1982) that the support of profits by government expenditure is crucial for avoiding the downward revision of future income expectations and so of planned investment. The intervention of the state to support profits by increasing expenditure is as important as the provision of liquidity. In the last financial crisis, the first and main role of the state has been that of reconstructing markets. This is what distinguishes current interventions from those made in other occasions.

This is also what justifies the reading of Minsky's theory according to the structural instability hypothesis. For the system to restart, the first step has been that of restoring the normal working of markets. However, this policy will not trigger a healthy recovery process if the structural conditions that led to the crisis are not dealt with. The existence of many Ponzi units, so tightly linked to each other, was the result of an environment where striving for high profits was mandatory. High profits should be obtained with all available means. In this context, even 
Ponzi behavior was considered a normal business practice. So, unless the rules change to prevent financial and nonfinancial units from behaving as Ponzi units, the problem will not be solved. It is not sufficient to inject liquidity and raise expenditure; structural conditions must be changed. Otherwise, the next crisis may be just around the corner.

Further, these interventions, in the absence of a serious reform of the financial system, will sustain the profits of the financial institutions. The profits of financial firms in the United States in 2007 amounted to about 45 percent of total profits, as measured in the national accounts. The goal of economic policy should not be to restore this situation. A parallel can be drawn with Minsky's theories about the relative stability of the system being warranted by a lax fiscal policy, which supported nonfinancial firms' profits and at the same time paved the way to a stagflationary environment. Mutatis mutandis, in a historical period in which productive investment contributed so little to the growth of national product and the process of financialization was so widespread, the central bank avoided the crisis until 2007. It supported banks' and financial institutions' profits by allowing an enormous asset price inflation to develop (see De Cecco 1999). Similarly, the measures taken after the crisis were aimed at restoring assets prices, which seem to have succeeded in reviving markets, including the stock exchange. However, the danger arises that all these interventions will merely allow financial institutions to operate in exactly the same way as before the crisis (see De Cecco 2009).

The reading of Minsky, according to the structural instability hypothesis, allows us also to sketch some policy prescriptions that go beyond the common goals of recovery, stated by looking at macroeconomic indicators such as growth of national income, employment, and so on. We have seen that the stability range of the financial system before the crisis was tiny. A very small shock can cause a big crisis. This is indeed what happened. Thus, to avoid the same process repeating itself in the future, it is necessary to enlarge this stability field. This would mean changing regulations in a way that the individual and collective behaviors that led to the crisis be hindered or discouraged. Simply strengthening capital requirements and supervision for financial institutions is not sufficient. As Tymoigne (2009) writes, the criteria for evaluating creditworthiness must be changed to avoid institutions from growing and prospering by using Ponzi-type business schemes. He suggests that cash flow projections be used to assess creditworthiness. In fact, structural instability greatly increased because of the high number of Ponzi agents strictly interacting with one another.

\section{Conclusion}

We have seen how Minsky's theory of financial fragility may be applied to the current crisis, if it is interpreted in a general sense as a theory of structural instability. This means not to rely on specific business cycle models based on investment. In particular, the reading by Minsky of the roles of the central bank in the presence of sophisticated 
markets and securitization is helpful for understanding both the failure of the Federal Reserve in preventing the crisis and the relative success in mitigating its effects. This apparent success notwithstanding, economic policy, to promote stability, must enlarge the stability field of the system by changing the types of institutions operating there and their business habits. Although the economy shows signs of macroeconomic recovery, the stability of the system in the long run does not seem to have become a goal of current policies. The dangers of a tiny stability field are thus still present.

\section{References}

Adrian, T., and M. Fleming. 2005. "What Financing Data Reveal About Dealer Leverage." FRBNY Current Issues in Economics and Finance 11, no. 3: 1-7.

Adrian, T., and H.S. Shin. 2008a. "Liquidity, Monetary Policy and Financial Cycles."

FRBNY Current Issues in Economics and Finance 14, no. 1: 1-7. . 2008b. "Liquidity and Leverage." FRBNY Staff Reports, no. 328 (May).

Bank for International Settlements (BIS). 2009. BIS Quarterly Review (March).

Bellofiore, R., and P. Ferri, ed. 2001. Financial Fragility and Investment in the Capitalist Economy: The Economic Legacy of Hyman Minsky. Vol. 2. Cheltenham, UK: Edward Elgar.

Bellofiore, R., and J. Halevi. 2009. "A Minsky Moment? The Subprime Crisis and the 'New' Capitalism.” Working Paper no. 2009-04, International Economic Policy Institute. Available at www.iepi.laurentian.ca.

Bernanke, B. 2009. "The Crisis and the Policy Response." Speech delivered as the Stamp Lecture at the London School of Economics, January 13. Available at www .federalreserve.gov.

Brunnermeier, M.K. 2009. "Deciphering the Liquidity and Credit Crunch 2007-8." Journal of Economic Perspectives 23, no. 1 (Winter): 77-100.

Buiter, W., and A. Sibert. 2007. "The Central Bank as a Market Maker of Last Resort: From a Lender of Last Resort to a Market Maker of Last Resort.” Vox (August 13). Available at www.voxeu.org/index.php?q=node/459/.

D’Arista, J. 2009. "Setting an Agenda for Monetary Reform.” PERI Working Paper no. 190, University of Massachusetts at Amherst.

Davidson, P. 2008. "Is the Current Financial Distress Caused by the Subprime Mortgage Crisis a Minsky Moment? Or Is It the Result of Attempting to Securitize Illiquid Noncommercial Mortgage Loans?" Journal of Post Keynesian Economics 30, no. 4 (Summer): 669-76.

De Cecco, M. 1999. “The Lender of Last Resort.” Economic Notes 28, no. 1: 1-14. 2009. "Il ricatto della grande finanza" [The Blackmail of Big Finance]. $L a$ Repubblica Financial Supplement (September 14): 1.

Dodd, R. 2007. "Subprime: Tentacles of a Crisis." Finance and Development 44 (December): 15-19.

Erturk, A.K., and G. Ozgur. 2008. "Endogenous Money in the Era of Financial Liberalization." Department of Economics, University of Utah.

Fleming, M.J.; W.B. Hrung; and F. Keane. 2009. "The Term Securities Lending Facility: Origin, Design and Effect." Federal Reserve Bank of New York Current Issues in Economics and Finance 15, no. 2: 1-10.

Goodhart, C.A.E. 1993. "Can We Improve the Structure of Financial Systems?" European Economic Review 37, nos. 2-3: 269-91.

Keister, T.; A. Martin; and J. McAndrews. 2008. "Divorcing Money from Monetary Policy." FRBNY Economic Policy Review (September): 41-56. 
Kregel, J. 2008. "Minsky's Cushions of Safety, Systemic Risk and the Crisis in the U.S. Subprime Mortgage Market." Public Policy Brief, no. 93, Jerome Levy Economics Institute, Annandale-on-Hudson, NY.

Minsky, H. 1982. Can "It" Happen Again? Essays on Instability and Finance. Armonk, NY: M.E. Sharpe.

2008. "Securitization.” Policy Note, no. 2, Jerome Levy Economics Institute, Annandale-on-Hudson, NY.

Papadimitriou, D., and G. Hannsgen. 2009. "Recent Rise in Federal Government and Federal Reserve Liabilities: Antidote to a Speculative Hangover." Strategic Analysis, no. 2 (April), Jerome Levy Economics Institute, Annandale-on-Hudson, NY.

Rochon, L.-P., and S. Rossi. 2007. "Central Banking and Post Keynesian Economics." Review of Political Economy 19, no. 4: 539-54.

Tymoigne, E. 2009. "Securitization, Deregulation, Economic Stability, and Financial Crisis: Part II, Deregulation, Financial Crisis and Policy Implications." Levy Economics Institute of Bard College Working Paper, no. 573.2.

Vercelli, A. 2001. "Minsky, Keynes and the Structural Instability of a Sophisticated Monetary Economy." In Financial Fragility and Investment in the Capitalist Economy: The Economic Legacy of Hyman Minsky. Vol. 2, ed. R. Bellofiore and P. Ferri, 33-52. Cheltenham, UK: Edward Elgar. 